\title{
The sky is the limit?! Evaluating the existence of a speculative bubble in European football
}

\section{Lukas Richau $^{1}$ (D) $\cdot$ Florian Follert $^{2} \cdot$ Monika Frenger $^{3} \cdot$ Eike Emrich $^{3}$}

Accepted: 30 September 2020 / Published online: 24 October 2020

(c) Springer-Verlag GmbH Germany, part of Springer Nature 2020

\begin{abstract}
In light of increasing salaries and transfer fees, the present study investigates the existence of a speculative bubble in European football. By applying the Kindleberger-Minsky model to football, we show that developments in recent years do not meet the criteria of a classic bubble. Although transfer fee spending in recent years does meet the typical pattern seen in historical bubbles, the case of football rather resembles an atypical bubble. This is because the rise in transfer fees for most clubs is largely backed by cash inflows, prompting an elevator effect for transfer fees. Typical bubbles, on the other hand, contain heavy debt-financing in the absence of respective and sustainable cash inflows. Nevertheless, despite the absence of a speculative bubble on the aggregated league level, some individual clubs seem to "live in a bubble". Furthermore, the French and especially Italian leagues should be cautious about overspending. We further discuss the main risk factors that can lead to a turning point in European football's constant revenue growth, including potential implications of a financial downturn.
\end{abstract}

Keywords Speculative bubbles · Kindleberger-Minsky model $\cdot$ Football $\cdot$ Transfer market $\cdot$ Financial investors $\cdot$ Football TV broadcasting

JEL Classification $\mathrm{G} 40 \cdot \mathrm{Z} 22 \cdot \mathrm{Z} 23 \cdot \mathrm{Z} 29$

Lukas Richau

lukas.richau@gmail.com

1 Faculty of Economics and Social Sciences, Helmut-Schmidt-University, Hamburg, Germany

2 Faculty of Management, Seeburg Castle University, Seekirchen, Austria

3 Faculty of Human and Business Sciences, Saarland University, Saarbrücken, Germany 


\section{Introduction}

Speculative bubbles are not a new phenomenon despite the New Economy and housing bubbles being two prominent examples in recent years. Indeed, cases such as the Tulip mania indicate that market bubbles have existed in the markets hundreds of years ago. Historical examples further illustrate that speculative bubbles are not limited to a few industries but can occur in all markets that feature floating prices (Kindleberger and Aliber 2005). In such cases, markets show a stable pattern of prices rising sharply to a high, followed by a subsequent turnover and a collapse to the extent of a bubble-and-crash pattern. This price movement pattern is of interest to economists since such (extreme) price movements are problematic for economies as a whole. Market prices influence the investment decisions of market participants and have a direct impact on companies' financing costs. As a result, extreme price movements in financial markets such as those observed in bubble-and-crash patterns can (negatively) affect the so-called "real economy" through spillover effects (for an evaluation of whether it is possible to design markets that preclude such bubble-and-crash patterns, see Palan 2009).

As a recent example, European football saw astonishing price developments (relative to historic prices) in the past years, which are garnering considerable public attention. Although discussions concerning the risk of an emerging bubble in football already occurred in 2012 (Lill 2012), recently the subject has attracted renewed interest-further fueled by the COVID-19 pandemic and its associated uncertainty for the football industry (Follert and Daumann 2020; Klosok 2020). In past transfer periods, clubs have repeatedly set new transfer fee records, at both aggregated and individual-player levels. Although the English Premier League drives this development to some degree, the pattern is also present in the other four top European Leagues, which include Spain (LaLiga), Germany (Bundesliga), Italy (Serie A), and France (Ligue 1). Based on this trend, transfer fee developments in the football market have been compared to a speculative bubble (e.g., Brennan 2017; Smith 2019).

The football market is of particular interest since it is traditionally characterized by an overinvestment environment with low profitability and high debt levels (Franck 2010a). In this sense, the present COVID-19 crisis can be seen as a kind of stress test for the financial stability of European football showing the weaknesses of the current system. Because of mounting criticism of exorbitant transfer fees, the current study investigates whether there are indicators of a speculative bubble (in an economic sense) in European football to assess the financial stability of European football. By applying the Kindleberger-Minsky model to European football, the study is conceptual in nature, which is complemented by quantitative key indicators used to assess the risk of a speculative bubble in other industries (e.g., the housing market).

The findings of this paper are, on the one hand, of practical relevance for football governing bodies and club managers. In the case of a speculative bubble, it could be an important implication for the international and national governing bodies to enforce stricter financial regulations beyond those existing (e.g., 
UEFA's Financial Fair Play). Moreover, club managers should be interested in this question to restrict their investment behavior in case of an emerging bubble and to ensure the club's financial stability. On the other hand, the results of our analysis should contest the public discussion about a speculative bubble in European football from an analytical perspective and should thus reduce the debate's emotional factor. Furthermore, the paper contributes to the large academic research stream focusing on financial stability and insolvencies in football.

The paper is structured as follows. First, we provide a short description of the football labor market and the clubs' financing, including an overview of the related literature (Sect. 2). We then present a theoretical framework and general definition for speculative bubbles alongside a description of the Kindleberger-Minsky model, which explains the different phases of a typical ${ }^{1}$ bubble. Next, we apply the model to the current situation in European football (Sect. 3). This is followed by a discussion of the main risk factors for the recent transfer fee growth (Sect. 4). Finally, we conclude our analysis in Sect. 5.

\section{Player trading, club financing and profitability in European football}

\subsection{Background and related literature on player trading and transfer fees}

Every market (e.g., stock exchanges, housing, arts, etc.) is defined by the existence of buyers and sellers who meet to trade goods and services (Mankiw and Taylor 2008, p. 73). Despite its peculiarities and restrictions (e.g., specific transfer periods), the football labor market is no exception (Franck 1995; Frick 2007). As a result, players can be seen as assets from an economic point of view (Morrow 1996) comparable to tulips, houses, or company shares, and this aligns with previous analyses (Tunaru and Viney 2010 use the term "vulnerable assets"). However, according to a more nuanced and technical definition, "it is not [...] the player himself who is the asset, but rather the provision of services" by a player in the future (Morrow 1996, p. 76). Football clubs, on the other hand, act as buyers and sellers who trade the football players' registrations. Clubs spend money to purchase player registrations to improve their roster and increase the club's utility. By owning player registrations, a club's utility can increase in two ways: either through a player's contribution to the club's sporting and commercial success during the contract period or by making a profit after selling the player at a price exceeding the initial acquisition costs, which is comparable to other investments for example in the stock market. Thus, a club does not necessarily look to sell a player registration at a higher price for a financial profit at a later date.

\footnotetext{
1 Although we are aware that the term "typical" in this context is controversial in economics, we follow the terminology of Kindleberger and Aliber (2005) based on the Kindleberger-Minsky model applied in this study.
} 
If a club is interested in buying a player from another club, the purchasing club has to contact the selling club. Transfer fees stem from negotiations and therefore constitute an agreement between the purchasing and selling clubs about the appropriate price. ${ }^{2}$ Like other labor markets, a crucial determinant of transfer fees and wages is the player's marginal revenue product, which represents the marginal utility a club can generate by signing a player (Daumann 2019, p. 182; Lucifora and Simmons 2003, p. 36). Consequently, clubs will be willing to pay a higher transfer fee in case of a higher marginal revenue product of the player.

Previous literature agrees that transfer fees (and, therefore, the players' marginal revenue products) are based on both club and player-related factors (e.g., Carmichael and Thomas 1993; Speight and Thomas 1997). Frick (2007) provides an overview of the early empirical studies that have evaluated the determinants of transfer fees and market values, whereby the latter are often used as proxies for actual transfer fees. ${ }^{3}$ Club-related factors include gate attendance and the club's sporting success (e.g., Speight and Thomas 1997). Player related factors have been categorized into four principal dimensions among other player characteristics: the player's human capital, performance, popularity and effort (Müller et al. 2017; Weimar and Wicker 2017). Examples of the player's human capital used in previous studies are the player's nationality and age (e.g., Carmichael et al. 1999; Muehlheusser et al. 2004; Dimitropoulos et al. 2018). In recent years, with an increasing number of companies focusing on the data gathering of football statistics, contemporary researchers can include a diverse set of player performance measures (the second dimension) such as passes, shots and tackles, including the respective success ratios (e.g., Herm et al. 2014; Richau et al. 2019). The third dimension (player popularity) refers to the superstar literature largely based on Rosen (1981) and Adler (1985) and examines the relationship between talent and popularity. Rosen (1981, p. 845) defines superstars as "relatively small numbers of people [who] earn enormous amounts of money and dominate the activities in which they engage". He claims that small talent differences lead to considerable earning differences due to a lack of adequate substitutes for great talent. Adler (1985), on the other hand, says that superstars emerge even in the case of equal talent because positive network externalities associated with popularity create a snowball effect. By analyzing the superstar phenomenon and the effect of popularity in football, previous studies have shown a positive effect of popularity-for example, operationalized as press citations (Franck and Nüesch 2012), Google hits (Herm et al. 2014) or social media followers (Frenger et al. 2019)—on the players' market values. As a fourth dimension, recently added to the discussion, Wicker et al. (2013) analyze the effect of effort (e.g., running distance) on market values, but find only insignificant or negative effects. An overview of the studies on market values and transfer fees mentioned above is provided in Table 1.

\footnotetext{
${ }^{2}$ For simplicity and in the presence of various contractual structures, we ignore other cases such as free agents, players on loan, etc.

${ }^{3}$ Herm, Callsen-Bracker and Kreis (2014) confirm a high correlation between market values and actual transfer fees. Similarly, Prockl and Frick (2018) show a high correlation between market values and salaries for the MLS.
} 


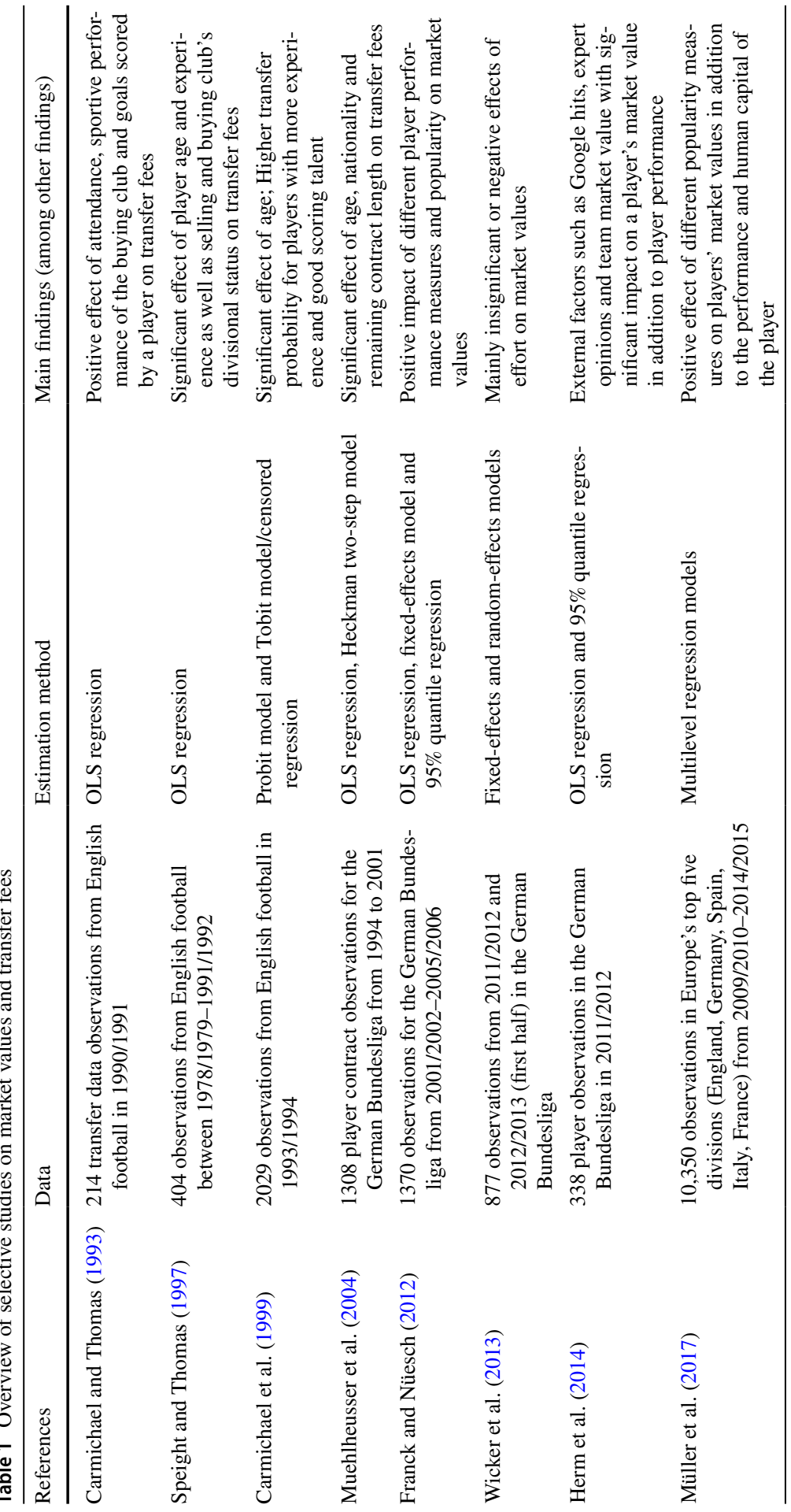




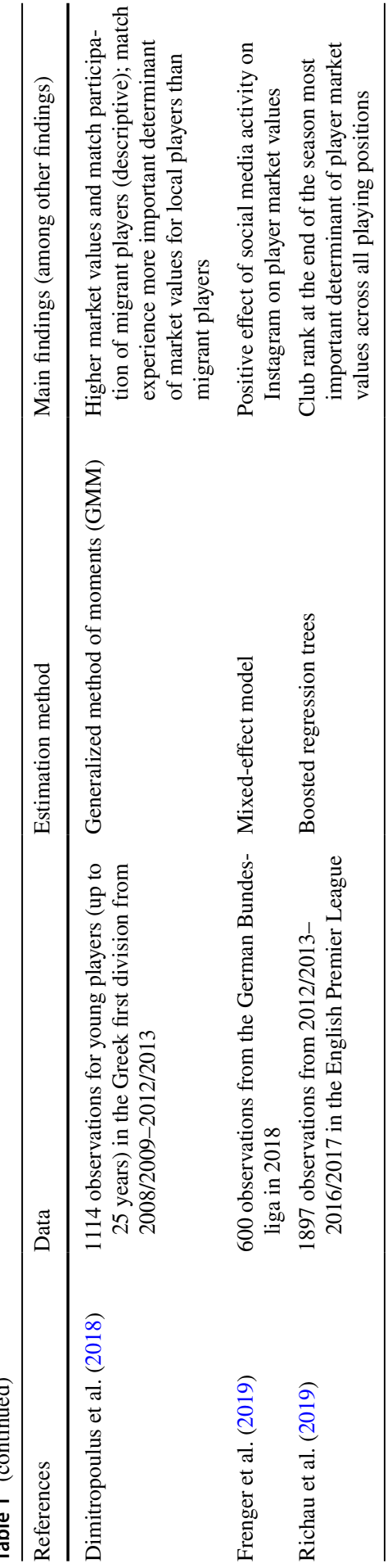


Still, despite numerous studies evaluating the determinants of transfer fees, the final price (so-called arbitration value, Matschke 1979) is the outcome of the negotiations (Follert et al. 2018) between the club that would like to buy a player and the selling club. If the negotiating parties respect their individual agreement conditions, both clubs increase their welfare. It is important to note, though, that the football labor market is judgment-based. Although various (objective) player statistics are available as shown above, the question of how to combine these statistics into a single number (i.e., market value or transfer fee) is disputed. Managers might assign a different weight to the various performance measures, which increases the extent of subjectivity in player valuations and transfer fee negotiations (for further information about judgments in markets that lack objective criteria, see Karpik 2011; Maurer and Mikl-Horke 2015) Hence, the selling and purchasing clubs might differ in their judgments regarding a fair price. Further, it is difficult to measure the individual marginal revenue product (i.e., payment streams) that a player will provide (e.g., through his contribution to the sporting success and his marketability) to the club since the value differs among clubs (Ackermann and Follert 2018). Given the absence of objective market values in the inherently imperfect football transfer market, past transfer fees of comparable players and other indicators (e.g., performance indicators, expert valuations) can be used as reference points in the negotiations (for market values as an argument in negotiations, see Ackermann and Follert 2018).

Furthermore, it is worth noting that the inherent bidding process on the football labor market might come with a winner's curse whereby the winning bidder overinvests (based on Capen et al. 1971). Previous research argues that this phenomenon exists also in the sports industry (Andreff 2012) such as baseball (Cassing and Douglas 1980). In the case of player trading, a winner's curse can exist if multiple clubs want to sign a player. This can force the winning club to acquire the respective player by spending more than the player's marginal revenue product (Andreff 2014). However, among other motives, a club might be willing to overinvest to prevent other teams from benefiting from the player's marginal revenue product (i.e., weakening other teams).

\subsection{Overview and related literature on club financing and profitability}

To finance transfers and meet other financial obligations, football clubs rely on internal and external financing. Their internal financing consists primarily of broadcasting, matchday, and sponsorship revenues whereby the major part of their revenue comes from broadcasting and sponsorship/commercial revenues in the major five leagues (Deloitte 2019; Dworak 2010). On the external side, football clubs can rely on multiple financial instruments, including bank loans, bonds, and money injections by external corporate or private partners (Berenberg 2015). For external suppliers of financial resources (e.g., banks), loans provided to sports clubs are especially risky since the outcome and respective returns of sports events resemble "a mix of predictability and gambling including a systematic tip" (Emrich et al. 2013 , p. 5, translated). Hence, the importance of bank loans for football clubs has decreased in past years due to the clubs' limited credibility. As an alternative, clubs, 
particularly in Germany, have tried to use other forms of external financing such as fan bonds (Weimar and Fox 2012).

Previous literature points out that the clubs' team investments (e.g., wages, transfer fees) have a positive effect on their sporting success (e.g., Forrest and Simmons 2002; Frick 2005). Thus, the more (internal and external) capital football clubs can generate, the higher their spending power on the labor market, which increases the probability of sporting success. Often Akerlof's (1976) metaphor of a "rat race" is used to explain the clubs' investment behavior where clubs overinvest to increase their chances of sporting success (e.g., Rohde and Breuer 2016). Previous literature supports that this investment behavior leads to an overinvestment environment with low profitability and the clubs' high debt levels (e.g., Dietl and Franck 2007; Franck 2010a, 2014). It is further argued that football clubs face a soft budget constraint (following Kornai 1979, 1980) that drives the overinvestment environment since, from a social perspective, clubs are too big to fail and stakeholders will bail out those clubs in financial distress (Andreff 2007; Storm and Nielsen 2012). A related topic discusses the circumstances for insolvencies in football, the key drivers for which are shocks (e.g., player injuries, relegation) that affect the clubs' financial stability (Scelles et al. 2018; Szymanski 2017; Szymanski and Weimar 2019). Beech et al. (2010) name (1) relegation, (2) outstanding tax payments, (3) soft debt turning into hard debt, (4) loss of stadium ownership and (5) repeat offenders as the main reasons for insolvency.

In light of the low profitability in European football, another recurring topic concerns the objective function of football clubs that discusses if football clubs act as win- or profit-maximizer. Sloane (1971) was first to note that European football clubs try to maximize wins under a financial break-even constraint, which aligns with today's principal view (e.g., Garcia-del-Barrio and Szymanski 2009; Kesenne 2002; Sloane 2015).

Besides the scientific contributions mentioned above, football-governing bodies (UEFA) and corporations (e.g., Deloitte) regularly publish studies that provide overviews of the financial state of (European) football. These are frequently cited in the existing academic literature (e.g., Storm and Nielsen 2012; Szymanski 2017) and thus underscore their relevance and reliability for academic and public discussion.

\section{Is there a speculative bubble in European football?}

\subsection{Speculative bubbles: definition and pattern from an economic perspective}

In economic terms, a speculative bubble exists if "assets trade at prices that are far in excess of an estimate of the fundamental value of an asset, as determined from discounted expected cash flows [...]"'(Vogel 2010, p. 16). ${ }^{4}$ Thus, the key element of

\footnotetext{
4 A further definition of bubbles is offered by Shiller $(2015$, p. 2): "a situation in which news of price increases spurs investor enthusiasm, which spreads by psychological contagion from person to person, in the process amplifying stories that might justify the price increases and bringing in a larger and larger class of investors, who, despite doubt about the real value of an investment, are drawn to it partly through envy of others' successes and partly through a gambler's excitement.".
} 
a bubble is the unsustainability of a given price structure that will eventually result in an implosion of the existing system (Kindleberger and Aliber 2005, p. 1). Minsky (1982, p. 13) describes the characteristics of bubbles and financial instability, ${ }^{5}$ stating that "the critical element in explaining why financial instability occurs is the development over historical time of liability structures that cannot be validated by market-determined cash flows or asset values. Thus, in a free market, wide and spreading bankruptcies can occur [...]". In particular, taking into account that the view of fully informed market participants is a fiction and that significant asymmetries exist among market participants, liabilities must be backed up with constant and proportionate revenue streams if financial instability are to be precluded based on Minsky's argumentation.

One framework that explains the pattern of speculative bubbles is the Kindleberger-Minsky model. Besides its application to several historical bubbles (e.g., Saqib 2001), the work of Charles Kindleberger — who built on a model by Hyman Minsky - drew renewed attention following the New Economy and housing bubbles (e.g., Gray 2009; Rosser, Rosser and Gallegati 2012). The Kindleberger-Minsky model takes a conceptual approach by separating the rise and burst of a speculative bubble into five phases, which characterize the typical pattern of such events: (1) displacement, (2) boom, (3) euphoria, (4) financial distress, and (5) revulsion (Fig. 1).

The first phase (displacement) involves some regulatory or other externally driven changes to the existing system that provide investors with new business opportunities. These opportunities are often promoted by the mass media and trigger the demand for these business opportunities. With the boom comes a price increase that

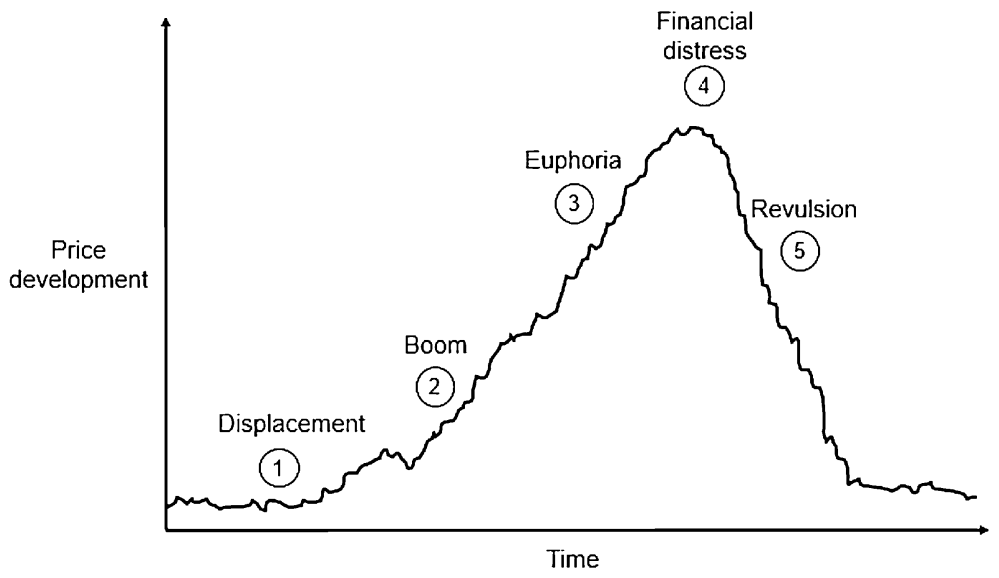

Fig. 1 (Illustrative) Kindleberger-Minsky bubble pattern (own illustration; source: Kindleberger and Aliber 2005)

\footnotetext{
5 Following Kindleberger and Aliber (2005, p. 1), "by definition a bubble involves a non-sustainable pattern of price changes or cash flows".
} 
starts slowly but accelerates quickly as the investment draws public attention; this results in a growing number of market participants. The price increase is driven by a growing and easier supply of (external) financial resources, which lead to higher investor indebtedness. Sources of financial resources can be financial institutions or private lenders, inter alia. The euphoria stage is accompanied by a strong belief that prices will rise indefinitely - although the inherent risk is acknowledged, individuals feel compelled to take part in these opportunities if they do not want to leave the competition. In this way, investments that fueled the price increase in the first place and brought high returns now attract even more investors. Prices become disconnected from established valuation concepts, given the belief that the asset can always be sold at a higher price while financial resources, as a prerequisite for the investment, can be accessed easily (Kindleberger and Aliber 2005, pp. 25-37). Thus, the success of the investment becomes a self-fulfilling prophecy (Merton 1948). Then, abruptly, following a supposedly unimportant event, prices begin to drop (financial distress). Market participants who rely heavily on debt financing for their investments find themselves in trouble, as the assumption of rising prices no longer holds. Investors need to off-load their assets to generate liquidity, which further erodes the price level. In the final phase (revulsion), prices drop rapidly to extremely low levels-until, for instance, a "lender of last resort" steps in and prices stabilize (Kindleberger and Aliber 2005, pp. 25-37).

According to Kindleberger and Aliber (2005, pp. 11-12), although speculative bubbles feature a similar pattern, their causes and origins can vary. From a financial perspective, however, the authors suggest that ease of access to financial resources (e.g., through low interest rates), which can result in unsustainable indebtedness, is a common element to speculative bubbles.

From one viewpoint, speculation can be considered the core of economics. As well as from a financial perspective, research has examined extreme price movements from a psychological perspective (for an overview of various psychological aspects, see Vogel 2010). In past discussions of extreme price movements, economists often assumed that investors behave rationally in their investment decisions. ${ }^{6}$ Blanchard and Watson (1982), for example, describe the concept of rational bubbles, whereby deviations from fundamental values can be deemed rational from an investment perspective.

This view of rationality, however, contrasts with observations made by studies that focus on psychological aspects. Among other findings, studies that focus on behavioral finance have found that people often adhere to their established beliefs and assumptions and thus oversee warning signals (Vogel 2010, pp. 79-80). Furthermore, bubble-building is often associated with the investors' herding behavior when they react to market signals and actions by other investors (for more details

\footnotetext{
6 As e.g., Emrich and Follert (2019)—based on Lindenberg (1985), Opp (1985), or Kirchgässner (2013) — describe, investors decide under uncertainty and try to maximize their expected benefit. Therefore, some decisions that seem to be irrational from an ex post perspective could be explained by the economic model of homo oeconomicus. Overall, there is often too much premature talk of irrational action when prices rise over a longer period. (For stock markets, see Olbrich [2000, p. 461, translated], who calls it "the irrationality of the irrationality thesis"; for more on transfer fees in football, see Follert 2018).
} 
on signaling, see Bikhchandani et al. 1998). In The Great Crash 1929, Galbraith (2009) explains this behavior: based on first successes with an investment, other (institutional and private) investors follow, which leads to a further (exponential) price increase. External pressure on all investors not to miss out on this business opportunity accompanies the herding behavior (Galbraith 1994); additionally, successful investors who jump on the bandwagon early signal the prospect of further rewards. A differentiation is made between rational and non-rational herding: while non-rational herding implies following other investors without considering personal information, rational herding means that investors lack personal information and must rely on information from other investors (Aytaç et al. 2018; for further details on rational herding behavior, see Bikhchandani and Sharma 2001). ${ }^{7}$

\subsection{Application of the Kindleberger-Minsky model to European football}

In the current debate, the question of a speculative bubble in football is based largely on the recent rapid increase in transfer fees (Fig. 2). A time trend analysis ${ }^{8}$ confirms a statistically significant increase of the aggregated transfer fee spending for all leagues (Table 2). The Premier League stands out with a trendline that shows an annual increase of $156.16 € \mathrm{M}$, which is almost three times higher than the increase of the other leagues. A time lagged regression further indicates that the transfer spending in the Premier League, Serie A and Bundesliga is to a large extent driven by the previous year's spending with an adjusted $R^{2}$ between 0.60 and 0.67 for these leagues (Table 3 ). In line with this discussion, we use transfer fees as a price indicator to examine the existence of a speculative bubble, by applying

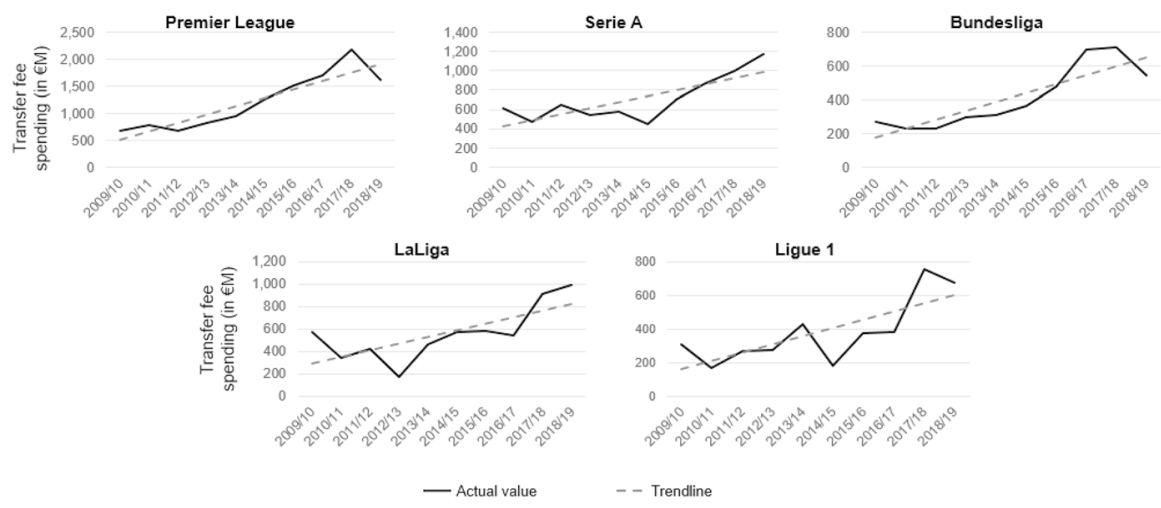

Fig. 2 Transfer fee spending (excl. loans), by league, 2009/2010-2018/2019 (incl. inflation) (own graph; sources: Transfermarkt.de 2019; Eurostat 2019)

\footnotetext{
7 Similarly, there is a large literature stream on anti-herding (see Spyrou 2013) including evidence for anti-herding of analysts (e.g., Pierdzioch, Rülke and Stadtmann 2012).

${ }^{8}$ Due to the separate analysis of each league and the limited number of observations by league, we do not apply other statistical methods such as stationarity tests or structural break analyses (e.g., Hadamitzky 2010, p. 187; Gengenbach, Palm and Urbain 2009).
} 


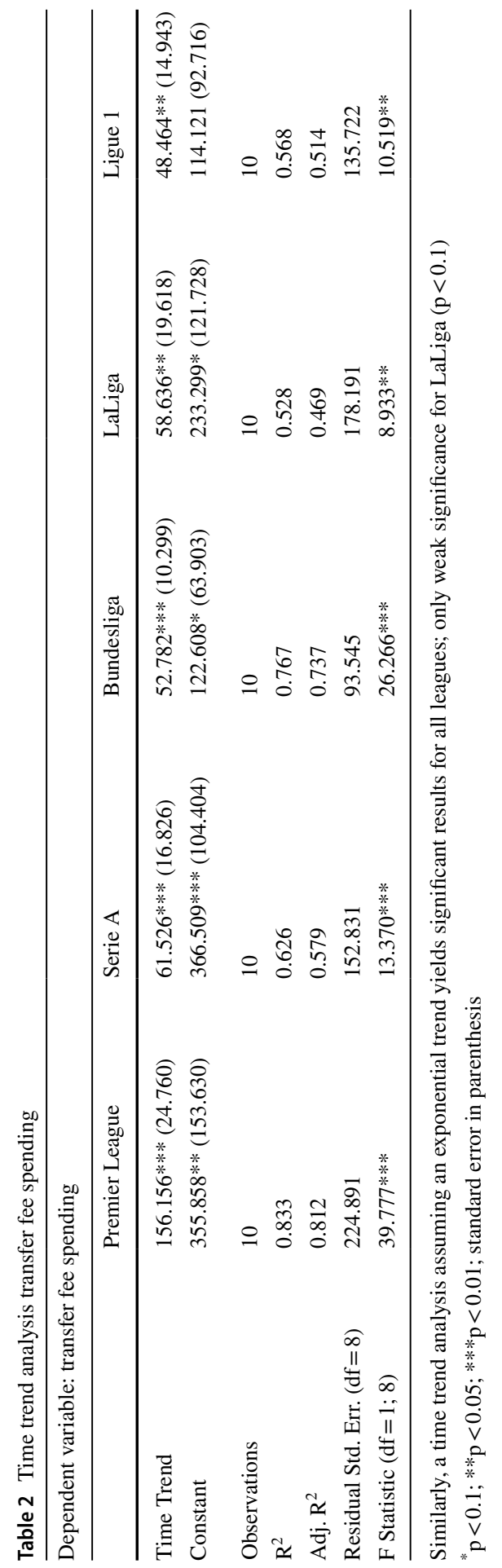




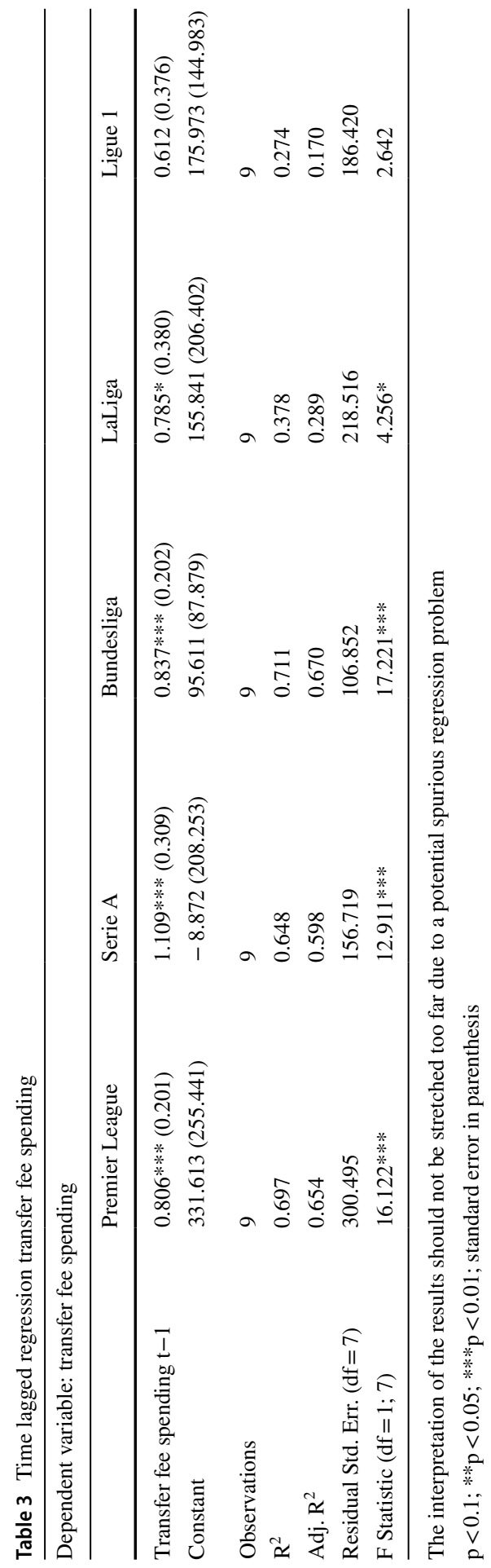


the Kindleberger-Minsky model to the football market. In so doing, we divide the development in European football into the first three Kindleberger-Minsky stages (i.e., displacement, boom, euphoria).

\subsubsection{Displacement: exogenous shock that changes business opportunities}

Based on the Kindleberger-Minsky model, it appears that a structural or regulatory change in the market opens or creates new business opportunities. In football, the development within the last decade can be traced to three main "exogenous shocks", besides some overarching developments. As such, although the individual shocks did not automatically lead to an immediate jump in revenues, the changes laid the foundation for recent-year developments and can thus be considered "displacements" in the sense of the Kindleberger-Minsky model. While revenues and transfer fees in European football have been growing for several decades (Deloitte 2015, p. 2 ), the past decade (especially the last 5 years) have shown increases beyond levels seen in previous decades. Because these recent changes have triggered the public discussion of whether there is a speculative bubble in European football, we focus on the revenue growth in the ten most recent years in this study.

The first "shock" concerns the transfer system in European football. Although they had only an indirect effect on today's growth in transfer fees, the regulatory changes regarding the transfer system laid the foundation for today's trading of player registrations. Starting with the Bosman ruling in 1995, players whose contracts had expired were allowed to move to a new club without the previous club being compensated by a transfer fee (Büch 1998; Feess and Muehlheusser 2003). This change, representing the first liberalization of the football labor market, was followed by the Monti system in 2001 (as well as by later adjustments), which set the contract duration to a maximum of 5 years. In 2002, the UEFA limited transfers to two transfer periods - one in the summer and one in the winter (Warshaw 2002).

A second regulatory intervention, driven by a government investigation, changed the bidding process for (domestic) live TV broadcasting rights in Europe. Besides limiting the duration of TV broadcasting contracts to 3 years in the United Kingdom, the "No-Single-Buyer-Rule" came into effect starting with the sale of TV rights for the 2007/2008-2009/2010 seasons in the English Premier League. The intention of the rule was to ensure fair competition in the football broadcasting rights market by guaranteeing the sale of live packages to more than one bidder (Connolly 2018).

The entry of (foreign) private financial investors, as the third "shock", started in 1997 with Mohamed al-Fayed taking over FC Fulham. The actual starting point of an increased number of (foreign) financial investors, however, was the entry of Roman Abramovich in 2003 at Chelsea London. Following this prominent example, European football has seen an increasing number of non-European investors taking over football clubs (Rohde and Breuer 2016). Despite different investor types and motives, it appears that media-attracting examples such as Paris Saint-Germain and Manchester City have had a considerable impact on the economic development of European football. 


\subsubsection{Boom: money begins to flow into the market}

As a consequence of these displacements, more money than ever began to flow into the market that the clubs could spend for example on player transfers; these inflows primarily comprised broadcasting revenues and money injections by financial investors. To understand the drivers of rising cash inflows, we now examine the economic processes behind the boom phase.

By evaluating the increase in TV broadcasting revenue, we find that on both the demand and supply sides, some changes occurred based on the regulatory changes. We illustrate the rise by focusing on the English Premier League, as the most prominent example. However, other leagues — such as the German Bundesliga-have shown similar trends (albeit to a lesser degree) and comparable underlying reasons for the increase (despite some local peculiarities and different starting points).

As described, one major driver in the increase in domestic and international broadcasting income (Fig. 3) has been intensified competition in the bidding process. The joint selling approach to the sale of broadcasting rights seen in most leagues_in which there is only one seller (i.e., the respective league)_prompted regulatory intervention that sought to prevent collusion and ensure innovation as well as a fair and competitive bidding process in the upstream market of TV broadcasting rights. Following an intervention in England as the first major European league, England, Italy, France, and Germany now all have in place the "No-SingleBuyer-Rule" (Ramcke 2018). On the supply side, to allow more broadcasting companies to tender a successful bidding attempt, the leagues increased the number of packages offered at the auction. The Premier League, for example, offered four live broadcasting packages in the bidding process for 2004/05-2006/07; this increased to

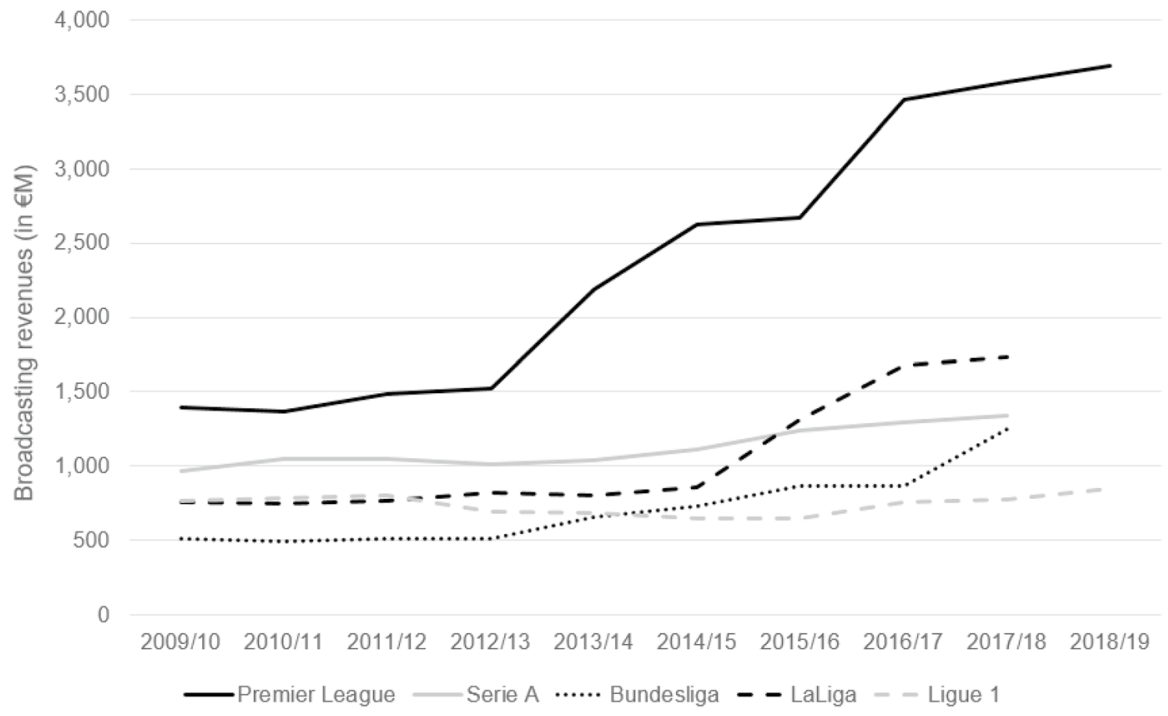

Fig. 3 Broadcasting revenue, by league (incl. inflation) (own graph; sources: UEFA 2017, p. 73; Eurostat 2019) 
six in the following period and seven for the 2013/2014-2015/2016 auction (Connolly 2018). One peculiarity of the English market is that not all games are included in the live broadcasting packages. Thus, to attract more bidders and increase prices, the league increased the number of live broadcasting matches in previous years to 200 (Kalenberg 2019). In Germany, for example, to increase the exclusivity of single matches for bidders and establish a second bidder besides Sky, the number of simultaneously played matches was reduced (Ramcke 2018).

The regulatory requirements and changes on the supply side also affected the demand side of the bidding process. In particular, it seems that new (international) competitors were challenging the incumbents. Given the necessity for (at least) two successful bidders, the chances of a successful bid for the individual companies increased, resulting in intensified competition from an economic perspective. The most relevant new competitor in the United Kingdom was British Telecommunications (BT), which entered the market before the 2013/2014 auction and led to a considerable revenue increase in the following two periods. Before BT entered the scene, Sky faced rather weak competitors that struggled to hold the rights for one period. Other new entrants in the Premier League in recent years have been ESPN, beIN, and Amazon. Markets in the other top leagues (e.g., Orange, Telefonica, and Vodafone in Spain) saw a similar increase in competitors (Connolly 2018; Ramcke 2018). Questions, however, arose concerning the profitability of the broadcasting companies, especially following the reduction of individual package sizes. Indeed, Feuillet et al. (2019) find a "winner's curse"- - not for the holder of the majority of the packages but for that with the smaller offering ("second winner"). From a financial perspective, broadcasting companies might nonetheless follow additional strategic objectives. One such objective could be to leverage the sports offering (e.g., football) to attract customers to their full product portfolio. In cases where such a strategy is used, broadcasting companies might accept low stand-alone profitability as a form of internal subsidization (Feuillet et al. 2019).

Beyond the regulatory requirements and increased competition, some complementary developments have been driving broadcasting revenues. One such development is the ongoing internationalization strategy of the European clubs, wherein the clubs especially focus on China and the United States as two large markets with high growth potential (Deloitte 2019, p. 2). By holding organized practices and matches in these countries as well as opening local offices, the leagues and clubs increase public awareness and their foreign fan base and thus increase demand for foreign broadcasting rights. One tangible result was the revenue increase from broadcasting rights, for domestic and international packages alike (UEFA 2017, p. 73). Moreover, the growing importance of digital media channels and social media provided clubs and leagues with new opportunities to promote the product internationally (McCarthy et al. 2014). Besides football, prices have increased for broadcasting and media rights for many other sports events worldwide (e.g., North American sports, Olympics), which underscores the great global marketing potential of major sports events (Chapman 2016; Crupi 2017).

The second driver to increase the financial means available to clubs is the entrance of financial investors, particularly in England, Italy, and France. Based on the increasing importance of international markets for the leagues, club ownership became more 
and more attractive to foreign investors (Deloitte 2015, p. 7). Today, club owners, especially in England but increasingly in Italy and France, come from all over the world. As for bubble-building and foreign cash inflows, it should be noted that past bubbles were further fueled by foreign investors (Sornette and Zhou 2004).

From the financial side, investors in football do not necessarily expect a financial return; in this sense, football clubs differ from typical investments (for a literature overview on club ownership and financial investors in European football, see Rohde and Breuer 2017). However, some investors might try to create direct financial gains by trading players or by increasing the value of the club and sell it at a higher price later (Bergin and Bryan-Low 2019). In the literature, US-American investors in particular are frequently considered profit maximizers (Nauright and Ramfjord 2010). A different category of investors follows strategic objectives, such as being involved in the business affairs of their club's home city (McGeehan 2019). Further, some investors look to generate some kind of positive externality through their club investment by promoting their main business or other investments (Franck 2010b).

In addition to these business-oriented motives, there is a reputational component that makes sports investments attractive to external individuals. Investors such as Chelsea London's owner Roman Abramovich seem to care most about the positive recognition about the good they are doing and the sporting success they bring to the club. Especially for investors looking for positive recognition, the football market (which is inherently emotional) is more promising than investments in other industries. This is because investments in football allow investors to be associated directly with the club's results in public discussions (Franck 2010a). In the case of institutional investors and investors connected to (foreign) governments, investments in sport (and in football clubs particularly) can serve as parts of a reputation management strategy and nation branding (Buschmann and Winterback 2019). Furthermore, football club ownership might also be a hobby for rich business people (Franck 2010b), as a kind of "conspicuous consumption" (Veblen 1973).

Besides the entry of financial investors, income from merchandising and advertising has grown; this, again, refers to the increased professionalization and commercialization that has taken place in European football and opened new revenue potential (Berenberg 2015). As a further driver for the revenue increase at least for the most successful teams, prize money in international competitions has increased considerably in recent years (Rohde and Breuer 2017).

\subsubsection{Euphoria: investor belief in ever-growing prices}

Although it remains unclear whether the European football market has reached the Kindleberger-Minsky "euphoria" stage, several key components of that stage indicate that euphoria is very unlikely in the football market, given its peculiarities. As Kindleberger and Aliber (2005, p. 13) note, price increases are often "accompanied by an increase in trading volume." $"$ Fig. 4, however, shows that there has been only

\footnotetext{
9 Similarly, Galbraith (2009) highlights the increasing trading frequency in his book about the Great Crash 1929.
} 


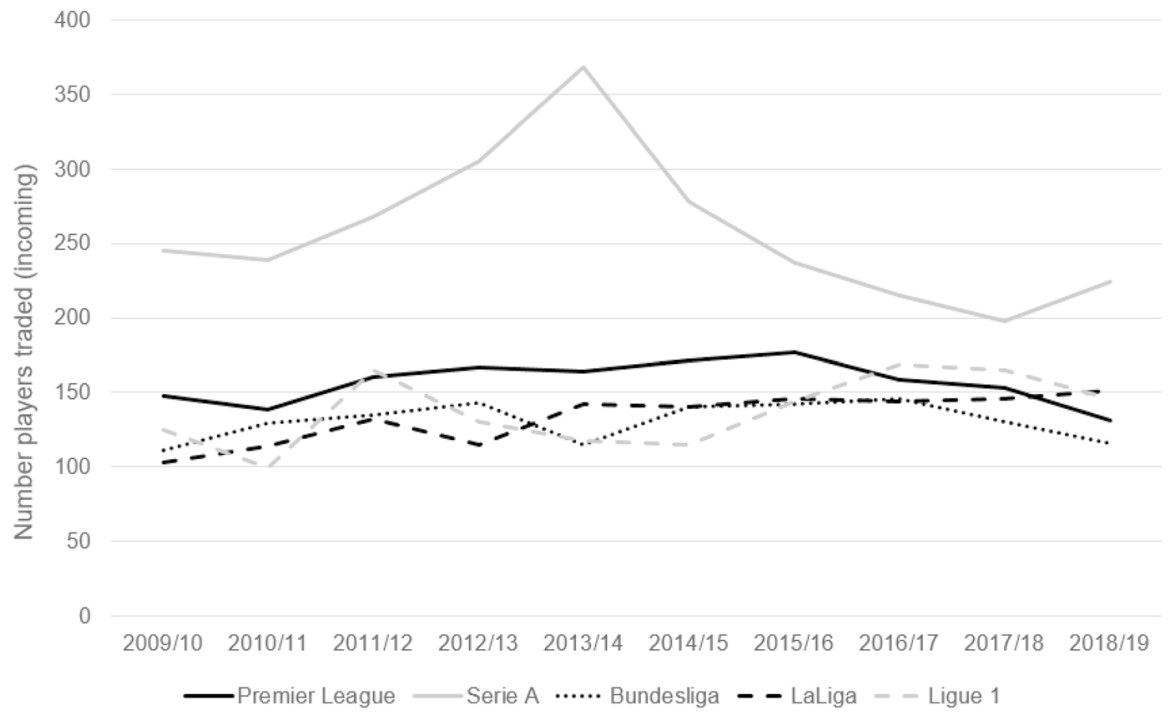

Fig. 4 Number of players traded (excl. loans and internal promotions) (own graph; source: Transfermarkt.de 2019)

a slight increase in trading volume (i.e., the number of new arrivals) in European football (except Spain), despite some variations. ${ }^{10}$

Most aspects that favor speculative trading - a characteristic of the euphoria stage - are regulated in the football labor market. First, the fixed and rather short transfer windows largely restrict the possibility of large fluctuations in, and speculations on, player values. Moreover, players can be registered for only up to three clubs per season (FIFA 2019, p. 10). Hence, football player registrations are not assets of a speculative nature, like company shares or other financial products with frequent trading and price changes. Further, it is not necessarily the club's objective to make a profit with player trading. As described, clubs can benefit from player registrations through their contribution to the team's sporting or commercial success. Unlike many other markets, only a small group of club managers can trade players, preventing those who lack the required expertise (e.g., hobby managers) and just follow others from investing in player registrations. As a consequence, only a small group of people drives the transfer fees (i.e., the price), which restricts excessive (irrational) herding behavior and the belief in ever-growing prices.

\footnotetext{
${ }^{10}$ AC Parma (Italy) with an exceptionally high number of player acquisitions in 2012-2015 until insolvency in 2015 due to business model of signing players and immediately lending them to other clubs (Mustroph 2015); loans and internal promotions not included.
} 


\subsection{Status quo in European football}

The recent development of transfer fees in European football-in particular the rapid increase from 2014/2015 to 2017/2018 - has followed a pattern resembling historical speculative bubbles as described by the Kindleberger-Minsky model. In particular, the Premier League stands out in both recent revenue and transfer fee increases.

Following Minsky (1982, p. 13), a bubble exists if the price increase is based on debt-financing and is not backed up by a sustainable cash inflow. Thus, the development in football is not critical as long as higher transfer fees are backed by a respective cash inflow (i.e., broadcasting income, investors) that allows clubs to meet current and future obligations. Additionally, in contrast to previous bubbles, the respective cash inflows presented in chapter 3.2.2 primarily represent actual revenues instead of external financing. ${ }^{11}$

To complement the findings from the Kindleberger-Minsky model, we analyze typical indicators for bubble-building used in other industries. In the housing market, the price-income ratio is a well-established indicator for testing speculative bubbles and financial stability (Rosser et al. 2012, p. 451); Deloitte uses the wagerevenue ratio in its yearly football report (Deloitte 2019, p. 11). As an extension, we check for the relation between club revenue and transfer fee spending, both on an aggregated level. We set revenues (excluding player trading) from $t-1$ in relation to transfer fee spending in $t$, assuming that clubs can spend their revenues in the following transfer window at the earliest. This indicator allows us to check the sustainability of the current transfer fees, in the sense that a rising ratio indicates that the growth in transfer fee spending is exceeding revenue growth.

Figure 5 shows a mixed picture by leagues. While a trend analysis (Table 4) shows no statistically significant increase for LaLiga, a small (significant)

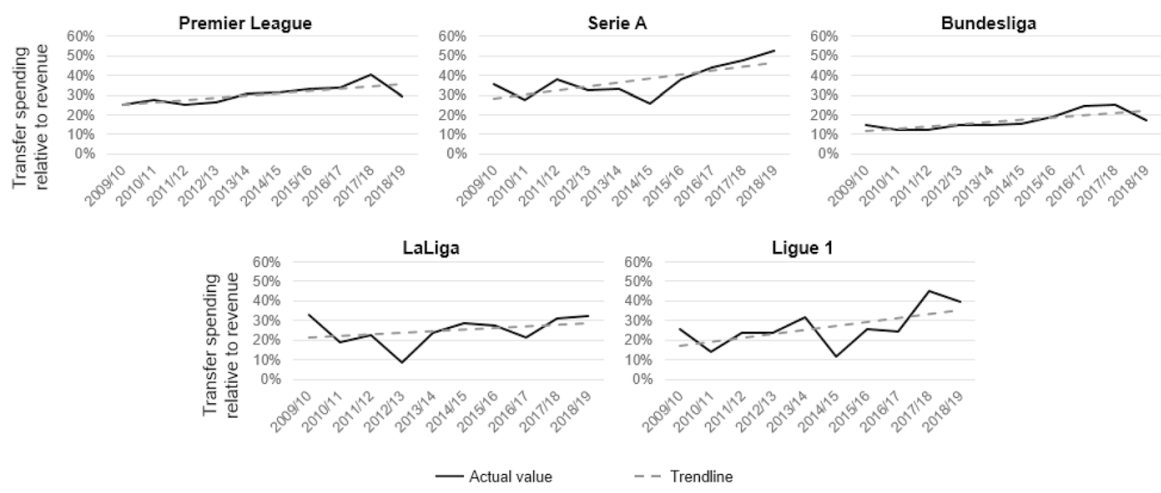

Fig. 5 Transfer fee-revenue ratio, by league (own graph and calculations; sources: Deloitte 2011-2019; Transfermarkt.de 2019)

\footnotetext{
11 Financial investors provide equity or soft loans. However, usually, these loans are not expected to be paid back (Beech et al. 2010) and are thus not comparable to typical loans known from historical crises.
} 


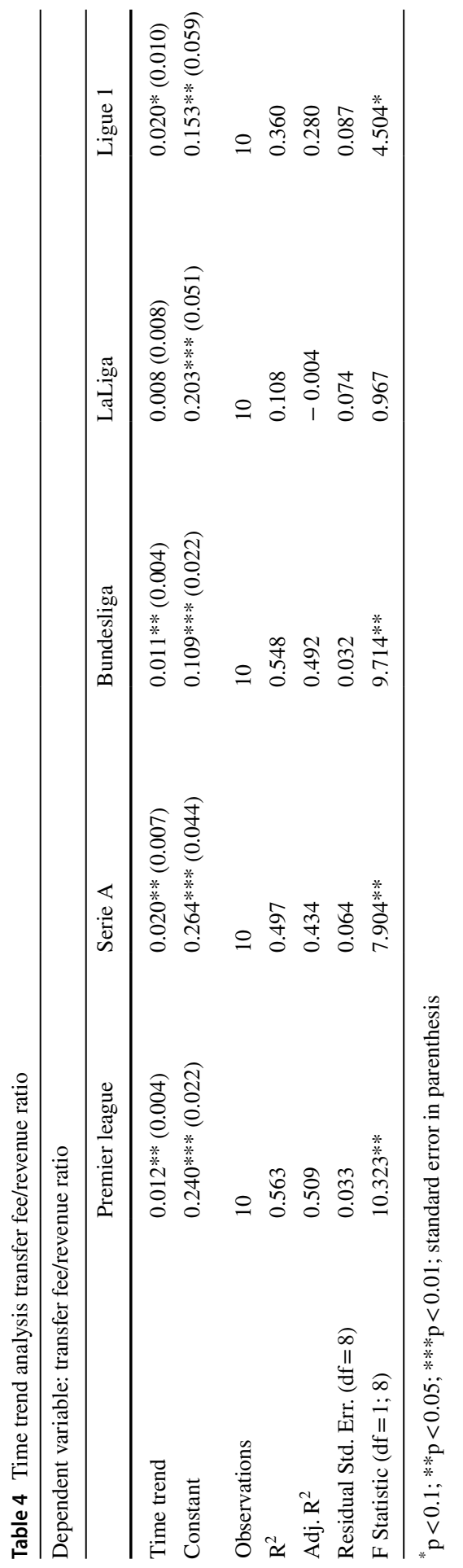


increase can be observed for the Premier League and Bundesliga. The Serie A and Ligue 1, however, show the highest annual increase of 0.02 in the trend analysis (statistically significant). Furthermore, the transfer fee/revenue ratio to a large extent depends on the ratio of the previous year in the Serie A compared to the other leagues (Bundesliga as an exception as shown in Table 5). This trend raises the question of the financial sustainability of the French and Italian leagues, since transfer fees constitute only one part of the expenses, while (player) wages, signing bonuses and other expenses (e.g., agent fees) also need to be paid.

As Fig. 6 shows, according to the latest figures, wage costs in Italy and France are also particularly high, relative to their revenues (i.e., $70 \%$ and $73 \%$, respectively). The wage situation in Italy and France needs particular monitoring, as $70 \%$ is considered the critical wage-revenue ratio threshold, assuming that no considerable income is generated from transfer activities. While Italy has significantly reduced its wage costs relative to revenues in recent years (Table 6), the latest

Table 5 Time lagged regression transfer fee/revenue ratio

\begin{tabular}{|c|c|c|c|c|c|}
\hline \multicolumn{6}{|c|}{ Dependent variable: transfer fee/revenue ratio } \\
\hline & Premier league & Serie A & Bundesliga & LaLiga & Ligue 1 \\
\hline $\begin{array}{l}\text { Transfer fee/Rev- } \\
\text { enue } t-1\end{array}$ & $0.420(0.311)$ & $0.754 *(0.394)$ & $0.675 * *(0.271)$ & $0.064(0.369)$ & $0.269(0.413)$ \\
\hline Constant & $0.181 *(0.096)$ & $0.107(0.143)$ & $0.058(0.048)$ & $0.223 * *(0.092)$ & $0.199(0.110)$ \\
\hline Observations & 9 & 9 & 9 & 9 & 9 \\
\hline $\mathrm{R}^{2}$ & 0.206 & 0.344 & 0.469 & 0.004 & 0.057 \\
\hline Adj. $\mathrm{R}^{2}$ & 0.093 & 0.250 & 0.393 & -0.138 & -0.078 \\
\hline $\begin{array}{l}\text { Residual Std. Err. } \\
\quad(\mathrm{df}=7)\end{array}$ & 0.043 & 0.079 & 0.037 & 0.077 & 0.113 \\
\hline $\begin{array}{l}\text { F Statistic }(\mathrm{df}=1 \\
7)\end{array}$ & 1.821 & $3.666^{*}$ & $6.190^{* *}$ & 0.030 & 0.424 \\
\hline
\end{tabular}

${ }^{*} \mathrm{p}<0.1 ; * * \mathrm{p}<0.05 ; * * * \mathrm{p}<0.01 ;$ standard error in parenthesis
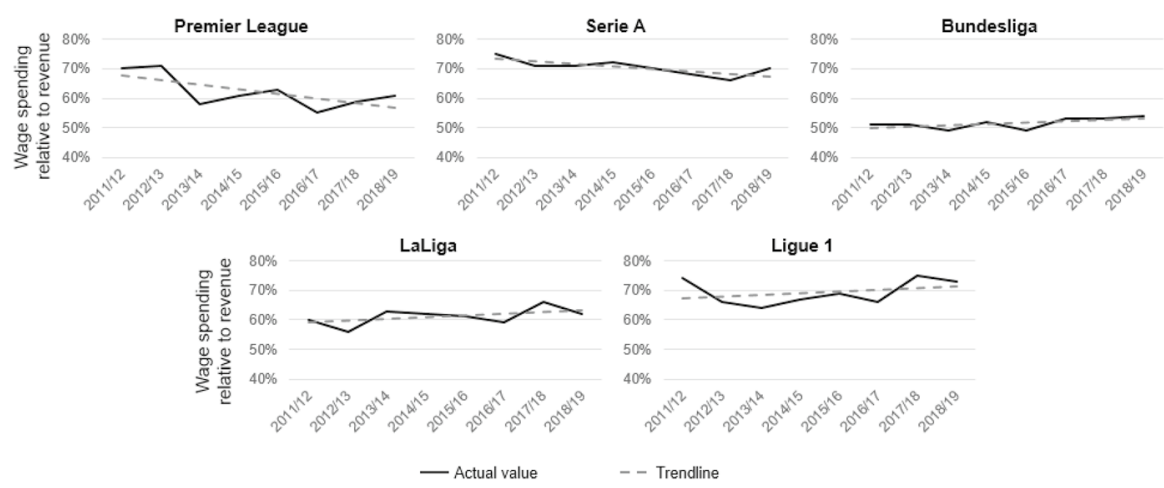

Fig. 6 Wage spending-revenue ratio, by league (own graph; sources: Deloitte 2013-2020) 


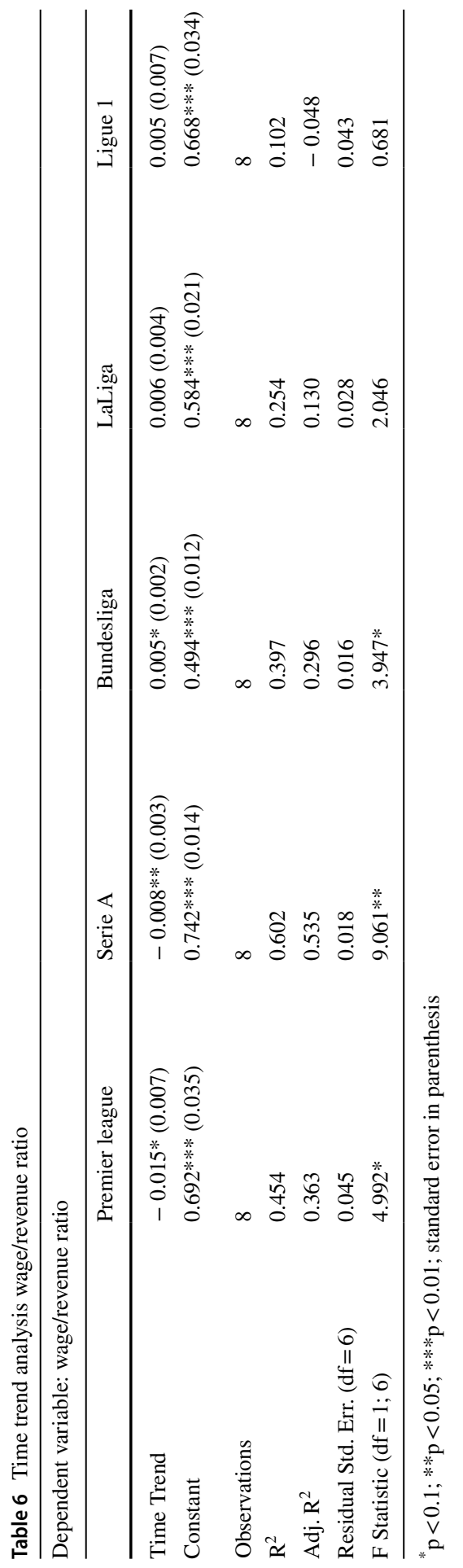


numbers show an increase again (Deloitte 2020, p. 11). Furthermore, the trend analysis shows that the Premier League is the league with the highest decrease of the wage/revenue ratio in the past years. The time lagged analysis again indicates that the wage-revenue ratio of the previous year has a higher influence on the indicator in the Serie A than in other leagues (indicated by $\mathrm{R}^{2}$ in Table 7).

Other important indicators are the club's debt-revenue ratio and (bottom-line) profitability. The debt-revenue ratio is presented in Fig. 7 and shows a stable development for the Bundesliga, LaLiga and Ligue 1 despite transfer fee increases in the past years. While the increase in FY2018 for the Premier League can be attributed chiefly to Tottenham's stadium investments (UEFA 2020, p. 126), the Serie A stands out in two ways: it shows a considerably higher ratio than other leagues and has experienced a further increase beyond the levels of the other leagues (except for the Premier League).

Looking at the profitability by considering both sides of player trading (i.e., buying and selling), the Italian clubs additionally reported a bottom-line loss of $€ 195 \mathrm{M}$ for FY2018. In France, the bottom-line loss of €51M in FY2017 was followed by

Table 7 Time lagged regression wage/revenue ratio

\begin{tabular}{llllll}
\hline Dependent variable: wage/revenue ratio & & & \\
\hline & Premier league & Serie A & Bundesliga & LaLiga & Ligue 1 \\
\hline Wage/revenue t-1 & $0.267(0.353)$ & $0.339(0.282)$ & $0.085(0.529)$ & $-0.133(0.441)$ & $0.141(0.422)$ \\
Constant & $0.445(0.222)$ & $0.458^{*}(0.198)$ & $0.472(0.271)$ & $0.694^{* *}(0.269)$ & $0.589^{*}(0.290)$ \\
Observations & 7 & 7 & 7 & 7 & 7 \\
$\mathrm{R}^{2}$ & 0.102 & 0.225 & 0.005 & 0.018 & 0.022 \\
$\begin{array}{l}\text { Adj. R } \\
\text { Residual Std. Err. }\end{array}$ & 0.052 & 0.070 & -0.194 & -0.178 & -0.174 \\
$\quad(\mathrm{df}=5)$ & 0.020 & 0.022 & 0.034 & 0.044 \\
F Statistic (df=1; 5) & 0.569 & 1.450 & 0.026 & 0.091 & 0.112 \\
\hline
\end{tabular}

${ }^{*} \mathrm{p}<0.1 ; * * \mathrm{p}<0.05 ; * * * \mathrm{p}<0.01 ;$ standard error in parenthesis

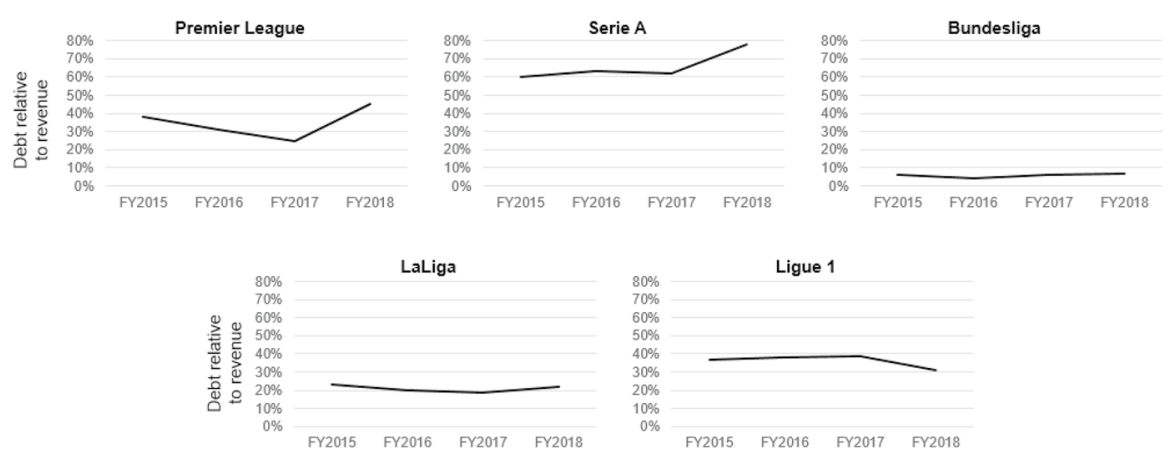

Fig. 7 Debt-revenue ratio, by league (own graph; sources: UEFA 2017-2020) 
a small profit in FY2018. Similar to the previous years, England, Spain, and Germany were the most profitable European leagues, with profits of $€ 382 \mathrm{M}, € 156 \mathrm{M}$, and $€ 153 \mathrm{M}$, respectively for FY2018 (UEFA 2020, p. 112).

Overall, despite some watch-outs in France and particularly Italy, the indicators suggest that, rather than a speculative bubble, there has been an "elevator effect"12 (Beck 2016, pp. 124-130) in European football. In addition to (pretransfer) revenue increases, football clubs in the five major European leagues not only buy player registrations at higher prices but also sell them at a higher level to mitigate or preclude bottom-line losses. Moreover, in looking at aggregated numbers, it becomes clear that a cumulative effect has further fueled the development of transfer fees. Since monetary circulation in football is partially closed, money injected into the market largely remains in the system by being circulated multiple times with each transfer among the clubs.

Hence, at this point, there seems to be no league-wide speculative bubble in economic terms based on recent transfer fee increases in any of the major European leagues, especially since cash inflows are largely based on economic processes rather than on speculative behavior. In this sense, the situation in European football can be defined as an atypical bubble: while showing a similar pattern to other bubbles, typical growing indebtedness ${ }^{13}$ without proper cash inflows is missing. However, France and especially Italy need to be careful not to further outgrow their cash inflows and slide into financial instability or even a bubble. Furthermore, accounting for player transfers incorporates some peculiarities that need to be considered when interpreting today's bottom-line figures: while transfer income is effective immediately after the sale, costs are distributed over a player's contract duration (UEFA 2019, p. 86).

While looking at aggregated data earlier, a deep-dive on the profitability indicates that some clubs might "live in a bubble" despite the absence of a league-wide bubble. However, with some clubs living beyond their means, this does not mean that the entire league is subject to a speculative bubble. Football club insolvencies are not uncommon (Szymanski 2017), and thus an individual insolvency does not automatically lead to a "bursting bubble," in the sense that the entire market will collapse. However, a chain reaction following multiple (and almost simultaneous) insolvencies among football clubs could entail just that. For the Premier League, Bundesliga, ${ }^{14}$ LaLiga and Ligue 1, a great majority of the clubs reported a bottomline profit for FY 2018. However, the club-level overview confirms that especially the Italian league should carefully monitor the investment behavior in order to avoid

\footnotetext{
12 The metaphor of an "elevator effect" refers to the increasing (absolute) wealth for the entire society in Western Germany following the Second World War and thus moving up with the elevator (Beck 2016). Based on the paradox of competition (see Grass and Stützel 1988), clubs can only improve their position if they increase their team investments more than other clubs (sentence about the mechanics of size). If, however, all clubs increase their team investments, relative sporting differences will remain. The result is just a higher spending behavior for all clubs (global sentence).

13 Except for FY2018 in England and Italy.

14 Slight increase in number of clubs with moderate bottom-line losses compared to FY2017 in the Premier League and Bundesliga.
} 
a potential bubble-building as the majority of the clubs reported a loss in FY2018, which represented a further worsening of the situation compared to previous years (UEFA 2020).

\section{Discussion}

In the past, the leagues and the UEFA have already implemented several measures, such as the Financial Fair Play regulations (Schubert and Lopez Frias 2019), to ensure the financial stability. Should the situation become more challenging, these regulations might be extended in the coming years. The results of this study show that especially the French and foremost the Italian league should carefully monitor the financial development and could consider to enforce stricter financial regulations if the situation does not improve.

Similar to the rapid revenue increase that drove the clubs' team investments in recent years, an opposite trend can lead to lower revenues. Two of the main associated risks are decreased broadcasting income and the exit of wealthy club owners. However, the risk of an immediate drop in revenue because of decreased broadcasting income is limited since contracts are negotiated 1 or 2 years before coming into effect. Thus, even in cases featuring lower contract values, clubs can adjust their team investments accordingly. Furthermore, it is unlikely that a rapid decrease will occur although the interruption due to COVID-19 caused some uncertainty regarding the broadcasting income for the 2019/2020 season. The Premier League, for example, experienced a slight decrease in its latest domestic broadcasting deal (2019/2020-2021/2022) rather than a drastic one; furthermore, this was offset by an increase in the international broadcasting deal (Deloitte 2019, p. 10). Still, these events might indicate that some leagues have reached a turning point, or at least a plateau, concerning domestic broadcasting contracts. However, given the lead time in advance of a drop in cash inflows, cash inflows from financial investors are more risky revenue sources. If the investor is heavily engaged in the club, such an exit can result in severe financial problems if there is no appropriate replacement.

If these risks were to occur and resulted in lower revenues, the risk of a leaguewide bubble would increase in case clubs do not adjust their spending behavior accordingly. The potential consequences of a bursting bubble would affect the sporting as well as financial dimensions of European football. From a financial perspective, pending payments for transfer fees, wages and other obligations would occur at a time of financial distress. Ultimately, the number of insolvencies among football clubs might increase, especially in the lower divisions.

This raises the question if managers should adjust their investment behavior in order to prepare for a potential (long-term) downturn. From the managers' perspective, however, the observable investment behavior seems rational. As managers are often judged according to the club's short-term success, they are incentivized to improve team quality, which requires higher investments instead of greater profitability. This aligns with the predominant view that clubs are win maximizers subject to a breakeven constraint. Manager behavior similarly aligns with the expectations of fans, who 
are generally more concerned with sporting success than with the club's financial stability - unless the club's financial stability is in question (Tunaru and Viney 2010, p. 5). This view is supported by previous research on insolvencies (e.g., Szymanski 2017) that indicates that often negative shocks rather than irrational behavior lead to insolvencies. Furthermore, higher profit requirements are seen as a competitive disadvantage in football's arms race (Franck 2010a). Thus, managers are not incentivized to prevent overspending and potential bubble-building. Nevertheless, from an economic perspective, it would certainly be recommended to use at least part of the additional cash inflow in a less risky way. Examples are investments in the club's long-term infrastructure, support for the local community, or increases in the club's equity as a capital buffer to prevent financial distress in case of decreasing revenues.

\section{Conclusion}

As shown in this study by applying the Kindleberger-Minsky model to football, the pattern of current developments in European football resembles that of an atypical bubble, with the characteristic shape of bubbles; however, unlike historical bubbles, there are proportionate cash inflows that justify the recent transfer fee increase for most of the clubs in Europe's five top divisions. From a contemporary perspective, the developments in football seem to be a continuation of the overall growth that the football market has experienced for decades, though fueled and accelerated in the last decade. Although some experts discuss the presence of a speculative bubble in football, it can also be argued that the football market was undervalued in previous decades and that better fundamentals (i.e., higher revenues) show higher marginal revenue products of the players and thus led to higher team investments in recent years. A study by the Berenberg bank (2015, p. 9, translated) sums up the developments in football: "higher revenues land in the pocket of the players due to intensive competition for these best players." When this thinking is brought to bear on the current study, it appears that this war for talent increases not only player wages but also transfer fees.

From today's perspective, it appears there are three possible scenarios for the future that ensure a sustainable development. First, revenues continue to grow, and this is accompanied by a further increase in transfer fees. Second, the current revenue and transfer fee levels become the "new normal" and remain at those same levels. Finally, the revenue drops, which would require the clubs to lower transfer fees. Especially with respect to the current COVID-19 crisis-which can be seen as a negative shock (following Szymanski 2017) not only for football but for the whole economy-decreasing revenues and hence decreasing transfer fees can be anticipated at least in the short-term. Thus, the crisis represents a stress test for the financial stability of European football and reveals the financial instability of some clubs. Although our study indicates that there is no bubble on an aggregated league level, the pandemic reinforces the financial problems especially for those clubs with unsustainable spending before the crisis.

The main limitation of this study is that it provides no final assessment. One peculiarity of bubbles is that they are impossible to predict in advance; thus, this paper provides only a conceptual evaluation that uses available parameters and 
considers the experiences of past bubbles and financial crises by applying the Kindleberger-Minsky model. Only future developments can conclusively indicate whether there is a bubble in European football. Hence, even the use of a more sophisticated approach would not yield a clear answer to the question of whether a speculative bubble exists. Other limitations concern the scope of this study. While focusing on the European top leagues, the financial stability in lower divisions might be more uncertain (e.g., Szymanski and Weimar 2019). Based on the observed tendency to gamble for success (Franck 2010a), it might be tempting for lower-division clubs to overspend to benefit from the considerably higher broadcasting income in the first division. Similarly, the risk of a bubble-building in the top divisions of other European countries that generate lower revenues or rely on selling home-grown talents might be higher if they simultaneously try to compete in the European "rat race".

The findings of this study suggest several promising areas for future research. First, the individual components of this study (e.g., economic mechanisms affecting broadcasting income and empirical studies on financial investors) can be further investigated. A second research stream relates to the role of agents in football contract negotiations. This is especially relevant because agents receive a provision for every transfer, based on its value, and therefore have a pecuniary interest in concluding as many transfers as they can. Third, in light of increasing transfer fees, loans are becoming more popular in football; this represents a different contract construct that deserves a closer look in future research. Finally, a troubling implication of transfer fee developments is that clubs are starting to scout players at even younger ages, to avoid high transfer fees, which opens new areas of strategic and ethical issues that should be addressed in future research.

Acknowledgements We thank three anonymous reviewers and Christian Pierdzioch for their valuable suggestions.

Funding No funding has been requested.

\section{Compliance with ethical standards}

Conflict of interest The authors declare that they have no conflict of interest.

\section{References}

Ackermann P, Follert F (2018) Einige bewertungstheoretische Anmerkungen zur Marktwertanalyse der Plattform transfermarkt.de. Sciamus Sport Manag 9(3):21-41

Adler M (1985) Stardom and talent. Am Econ Rev 75(1):208-212

Akerlof G (1976) The economics of caste and of the rat race and other woeful tales. Q J Econ 90(4):599_ 617. https://doi.org/10.2307/1885324

Andreff W (2007) French football: a financial crisis rooted in weak governance. J Sports Econ 8(6):652661. https://doi.org/10.1177/1527002506297021

Andreff W (2012) The winner's curse: why is the cost of sports mega-events so often underestimated? In: Maennig W, Zimbalist A (eds) International handbook of the economics of mega sporting events. Edward Elgar Publishing, Cheltenham, pp 37-69 
Andreff W (2014) The winner's curse in sports economics. In: Budzinski O, Feddersen A (eds) Contemporary research in sports economics 14. Peter Lang, Bern, pp 177-205

Aytaç B, Coqueret G, Mandou C (2018) Herding behavior among wine investors. Econ Model 68:318328. https://doi.org/10.1016/j.econmod.2017.07.022

Beck U (2016) Risikogesellschaft: auf dem Weg in eine andere Moderne, 23rd edn. Suhrkamp Verlag, Frankfurt am Main

Beech J, Horsman S, Magraw J (2010) Insolvency events among English football clubs. Int J Sports Mark Spons 11(3):53-66. https://doi.org/10.1108/ijsms-11-03-2010-b006

Berenberg (2015) Finanzierung im Profifussball. Berenberg Wirtschaftstrends. https://www.berenberg. de/files/MacroNews/150121_BERENBERG\%2520MAKRO_Trends_Finanzierung_im_Profifussb all_final.pdf. Accessed 21 May 2019

Bergin T, Bryan-Low C (2019) Wie investoren am transfer-boom im Fußball verdienen wollen. Reuters. https://www.reuters.com/article/europa-fussball-finanzinvestoren-idDEKCN1P11HV. Accessed 10 May 2019

Bikhchandani S, Hirshleifer D, Welch I (1998) Learning from the behavior of others: conformity, fads, and informational cascades. J Econ Perspect 12(3):151-170. https://doi.org/10.1257/jep.12.3.151

Bikhchandani S, Sharma S (2001) Herd behavior in financial markets. IMF Staff Papers 47(3): 279-310. https://www.imf.org/External/Pubs/FT/staffp/2001/01/bikhchan.htm

Blanchard OJ, Watson MW (1982) Bubbles, rational expectations and financial markets. In: Wachtel $\mathrm{P}$ (ed) Crises in the economic and financial structure. DC Heath and Company, Lexington, pp 295-316

Brennan A (2017) European soccer has an inflationary bubble that will eventually burst. Forbes Online. https://www.forbes.com/sites/andrewbrennan/2017/09/11/european-football-has-entered-an-infla tionary-bubble-and-it-will-burst/\#405c52741188. Accessed 13 May 2019

Büch MP (1998) Das “Bosman-Urteil”- transferentschädigungen, ablösesummen, eigentumsrechte, freizügigkeit. Sportökonomische Anmerkungen zu einem sportpolitischen Thema. Sportwissenschaft 28(3-4):283-296

Buschmann R, Winterback C (2019) Neue Enthüllungen belasten PSG-Chef. Spiegel Online. https:// www.spiegel.de/sport/fussball/nasser-al-khelaifi-neue-enthuellungen-belasten-psg-chef-a-12772 99.html. Accessed 13 Aug 2019

Capen EC, Clapp RV, Campbell WM (1971) Competitive bidding in high-risk situations. J Pet Technol 23(6):641-653

Carmichael F, Forrest D, Simmons R (1999) the labour market in association football: who gets transferred and for how much? Bull Econ Res 51(2):125-150

Carmichael F, Thomas D (1993) Bargaining in the transfer market: theory and evidence. Appl Econ 25(12):1467-1476

Cassing J, Douglas RW (1980) Implications of the auction mechanism in baseball's free agent draft. South Econ J 47(1):110-121

Chapman B (2016) Rio 2016: the richest games in 120 years of Olympic history. Independent Online. https://www.independent.co.uk/news/business/analysis-and-features/rio-2016-olympic-games -richest-ever-usain-bolt-mo-farah-a7171811.html. Accessed 13 Aug 2019

Connolly E (2018) The rights track: a history of the Premier League's UK TV deals. SportsPro. https ://www.sportspromedia.com/analysis/rise-premier-leagues-uk-tv-rights-income. Accessed 13 June 2019

Crupi A (2017) Sports Media Rights to soar to \$23B in 2021, PwC report says. https://adage.com/article/ media/pwc-report-sports-m/311578. Accessed 17 June 2019

Daumann F (2019) Grundlagen der Sportökonomie, 3rd edn. UKV Verlag, München

Deloitte (2011) Annual review of football finance 2011. https://www2.deloitte.com/content/dam/Deloitte/ uk/Documents/sports-business-group/uk-sbg-arff11-highlights.pdf. Accessed 25 Aug 2019

Deloitte (2012) Annual review of football finance 2012. https://www2.deloitte.com/content/dam/Deloitte/ uk/Documents/sports-business-group/uk-sbg-annual-football-finance-review-2012-highlights.pdf. Accessed 25 Aug 2019

Deloitte (2013) Annual review of football finance 2013. https:/www2.deloitte.com/content/dam/Deloi tte/uk/Documents/sports-business-group/deloitte-uk-sbg-arff-2013-highlights-download.pdf. Accessed 25 Aug 2019

Deloitte (2014) Annual review of football finance 2014. https://www2.deloitte.com/content/dam/Deloitte/ uk/Documents/sports-business-group/deloitte-uk-annual-review-football-finance.pdf. Accessed 25 Aug 2019 
Deloitte (2015) Annual review of football finance 2015. https://www2.deloitte.com/content/dam/Deloitte/ global/Documents/About-Deloitte/gx-deloitte-uk-arff-2015-highlights.pdf. Accessed 25 Aug 2019

Deloitte (2016) Annual review of football finance 2016.https:/www2.deloitte.com/content/dam/Deloi tte/global/Documents/consumer-industrial-products/gx-deloitte-uk-annual-review-of-football-finan ce-2016.pdf. Accessed 25 Aug 2019

Deloitte (2017) Annual review of football finance 2017. https:/www2.deloitte.com/content/dam/Deloi tte/global/Documents/About-Deloitte/gx-deloitte-annual-review-of-football-finance-2017.pdf. Accessed 25 Aug 2019

Deloitte (2018) Annual review of football finance 2018. https:/www2.deloitte.com/content/dam/Deloitte/ uk/Documents/sports-business-group/deloitte-uk-sbg-annual-review-of-football-finance-2018.PDF. Accessed 25 Aug 2019

Deloitte (2019) Annual review of football finance 2019. https://www2.deloitte.com/content/dam/Deloi tte/global/Documents/Consumer-Business/deloitte-uk-annual-review-of-football-finance-2019.pdf. Accessed 25 Aug 2019

Deloitte (2020) Annual review of football finance 2020. https://www2.deloitte.com/content/dam/Deloi tte/uk/Documents/sports-business-group/deloitte-uk-annual-review-of-football-finance-2020.pdf. Accessed 10 Jun 2020

Dietl H, Franck E (2007) Governance failure and financial crisis in German football. J Sports Econ 8(6):662-669. https://doi.org/10.1177/1527002506297022

Dimitropoulos PE, Travlos A, Panagiotopoulos S (2018) Migration and football player market value: evidence from Greece. Int J Sport Financ 13(2):119-140

Dworak A (2010) Finanzierung für Fußballunternehmen-Erfolgreiche Wege der Kapitalbeschaffung. Erich Schmidt Verlag, Berlin

Emrich E, Follert F (2019) Totgesagte leben länger! Einige Anmerkungen zum homo oeconomicus als Methode. Wirtschaftspolitische Blätter 66(3):337-347

Emrich E, Pierdzioch C, Rullang C (2013) Zwischen Regelgebundenheit und diskretionären Spielräumen: die Finanzierung des bundesdeutschen Spitzensports. Sport Gesellschaft 10(1):3-26

Eurostat (2019) Europäische Union and Euro-Zone: Inflationsrate von 2008-2018. https://de.statista.com/ statistik/daten/studie/156285/umfrage/entwicklung-derinflationsrate-in-der-eu-und-der-eurozone/). Accessed 14 June 2019

Feess E, Muehlheusser G (2003) Transfer fee regulations in European football. Eur Econ Rev 47(4):645668. https://doi.org/10.1016/S0014-2921(02)00308-2

Feuillet A, Scelles N, Durand C (2019) A winner's curse in the bidding process for broadcasting rights in football? The cases of the French and UK markets. Sport Soc 22(7):1198-1224. https://doi. org/10.1080/17430437.2018.1505869

FIFA (2019) Regulations on the status and transfer of players. https://resources.fifa.com/image/upload/ regulations-on-the-status-and-transfer-of-players-june-2019.pdf?cloudid=ao68trzk4bbaezlipx9u. Accessed 13 Aug 2019

Follert F (2018) Ökonomisierung des Fußballs. Das Wirtschaftsstudium (WISU) 6:668-670

Follert F, Daumann F (2020) “The show must go on”!? Sportökonomische Hintergründe zum Bundesliga Neustart in Zeiten von Covid-19. Wirtschaftliche Freiheit-Das Ordnungspolitische Journal. https ://wirtschaftlichefreiheit.de/wordpress/?p=27240

Follert F, Herbener JM, Olbrich M, Rapp DJ (2018) Agree or disagree? On the role of negotiations for the valuation of business enterprises. Q J Austrian Econ 21(4):315-338

Forrest D, Simmons R (2002) Team salaries and playing success in sports: a comparative perspective. In: Albach H, Frick B (eds) Sportökonomie. ZfB-Ergänzungshefte, vol 4. Gabler Verlag, Wiesbaden, pp 221-238

Franck E (1995) Die ökonomischen Institutionen der Teamsportindustrie. Deutscher Universitätsverlag, Wiesbaden

Franck E (2010a) Private firm, public corporation or member's association-governance structures in European football. Int J Sport Financ 5(2):108-127. https://doi.org/10.5167/uzh-35150

Franck E (2010b) Zombierennen und Patenonkel-Warum deutsche Fussballklubs in der Champions League den Kürzeren ziehen. Zfbf Sonderheft 62:1-13

Franck E (2014) Financial fair play in European Club Football—what is it all about? Int J Sport Financ 9(3):193-217

Franck E, Nüesch S (2012) Talent and/or popularity: what does it take to be a superstar? Econ Inq 50(1):202-216 
Frenger M, Follert F, Richau L, Emrich E (2019) Follow me...on the relationship between social media activities and market values in the German Bundesliga. Working Papers of the European Institute for Socioeconomics No. 32. https://www.soziooekonomie.org/fileadmin/soziooekonomie.org/pdf/ EIS_Workingpaper_32_2019.pdf. Accessed 10 Sep 2019

Frick B (2005) und Geld schießt eben doch Tore. Sportwissenschaft 35(3):250-270

Frick B (2007) The football players' labor market: empirical evidence from the major European leagues. Scott J Polit Econ 54(3):422-446. https://doi.org/10.1111/j.1467-9485.2007.00423.x

Galbraith JK (1994) A short history of financial euphoria, revised edn. Penguin Books, London

Galbraith JK (2009) The great crash 1929, revised edn. Penguin Books, London

Garcia-del-Barrio P, Szymanski S (2009) Goal! profit maximization versus win maximization in soccer. Rev Ind Organ 34(1):45-68. https://doi.org/10.1007/s11151-009-9203-6

Gengenbach C, Palm FC, Urbain JP (2009) Panel unit root tests in the presence of cross-sectional dependencies: comparison and implications for modelling. Econom Rev 29(2):111-145

Grass RD, Stützel W (1988) Volkswirtschaftslehre-eine Einführung auch für Fachfremde, 2nd edn. Verlag Vahlen, München

Gray DF (2009) Modeling financial crises and sovereign risks. Annu Rev Financ Econ 1:117-144. https ://doi.org/10.1146/annurev.financial.050808.114316

Hadamitzky A (2010) Der deutsche Krankenhausmarkt, Eine Analyse auf Basis des Konzepts zur Koordinationsmängeldiagnose. Gabler Verlag, Wiesbaden

Herm S, Callsen-Bracker HM, Kreis H (2014) When the crowd evaluates soccer players' market values: accuracy and evaluation attributes of an online community. Sport Manag Rev 17(4):484-492

Kalenberg S (2019) Absurde TV-Rechte in der Premier League: Warum Fans in England manche Spiele gar nicht sehen können. RP Online. https://rp-online.de/sport/fussball/international/england/tvrechte-in-england-so-absurd-ist-die-lage-in-der-premier-league_aid-37153057. Accessed 18 Sept 2019

Karpik L (2011) Mehr Wert: die Ökonomie des Einzigartigen, 1st German edn. Campus, Frankfurt am Main

Kesenne S (2002) The monopsonistic player labour market in a win-maximising league. Eur Sport Manag Q 2(3):180-187. https://doi.org/10.1080/16184740208721921

Kindleberger CP, Aliber RZ (2005) Manias, panics, and crashes-a history of financial crises, 5 th edn. Wiley, Hoboken

Kirchgässner G (2008) Homo Oeconomicus, 4th edn. Mohr Siebeck, Tübingen

Klosok A (2020) "Back To Reality": European soccer prepares for age of austerity. CNN. https://editi on.cnn.com/2020/06/01/football/european-soccer-coronavirus-pandemic-transfer-window-cmdspt-intl/index.html. Accessed 2 June 2020

Kornai J (1979) Resource-constrained versus demand-constrained systems. Econometrica 47(4):801-819. https://doi.org/10.2307/1914132

Kornai J (1980) "Hard" and "Soft" budget constraint. Acta Oeconom 25(3/4):231-245

Lill F (2012) Fußball in England: finanzblase Premier League. FAZ Online. https://www.faz.net/aktue 11/sport/fussball/fussball-in-england-finanzblase-premier-league-11859535.html. Accessed 22 July 2019

Lindenberg S (1985) An assessment of the new political economy: its potential for the social sciences and for sociology in particular. Sociol Theory 3(1):99-114

Lucifora C, Simmons R (2003) Superstar effects in sport: evidence from Italian Soccer. J Sports Econ 4(1):35-55. https://doi.org/10.1177/1527002502239657

Mankiw NG, Taylor MP (2008) Grundzüge der Volkswirtschaftslehre, 4th edn. Schäffer-Poeschel Verlag, Stuttgart

Matschke MJ (1979) Funktionale Unternehmensbewertung — Band II Der Arbitriumwert der Unternehmung. Springer Gabler, Wiesbaden

Maurer A, Mikl-Horke G (2015) Wirtschaftssoziologie. Nomos Verlagsgesellschaft, Baden-Baden

McCarthy J, Rowley J, Ashworth CJ, Pioch E (2014) Managing brand presence through social media: the case of UK football clubs. Internet Res 24(2):181-204. https://doi.org/10.1108/IntR-08-2012-0154

McGeehan N (2019) Die Wahrheit über die Besitzer von Manchester United: the Dark Side of Blue. 11Freunde Online. https://www.11freunde.de/artikel/die-wahrheit-ueber-die-besitzer-von-manch ester-city. Accessed 29 July 2019

Merton RK (1948) The self-fulfilling prophecy. Antioch Rev 8(2):193-210. https://doi.org/10.2307/46092 67 
Minsky HP (1982) The financial-instability hypothesis: capitalist processes and the behavior of the economy. Hyman P. Minsky Archive Paper No. 282. https://digitalcommons.bard.edu/cgi/viewconten t.cgi? article $=1281 \&$ context=hm_archive. Retrieved 15 Jul 2019

Morrow S (1996) Football players as human assets. Measurement as the critical factor in asset recognition: a case study investigation. J Hum Resourc Cost Account 1(1):75-97. https://doi.org/10.1108/ eb029024

Muehlheusser G, Frick B, Feess E (2004) Legal restrictions on buyout fees: theory and evidence from German soccer. IZA Discussion Papers No. 1180. https://hdl.handle.net/10419/20420

Müller O, Simons A, Weinmann M (2017) Beyond crowd judgments: data-driven estimation of market value in association football. Eur J Oper Res 263(2):611-624. https://doi.org/10.1016/j. ejor.2017.05.005

Mustroph T (2015) Bankrotter Traditionsclub: der Untergang des FC Parma. Spiegel Online. https://www. spiegel.de/sport/fussball/fc-parma-untergang-eines-traditionsklubs-a-1024295.html. Accessed 29 July 2019

Nauright J, Ramfjord J (2010) Who owns England's game? American professional sporting influences and foreign ownership in the Premier League. Soccer Soc 11(4):428-441. https://doi. org/10.1080/14660971003780321

Olbrich M (2000) Zur Bedeutung des Börsenkurses für die Bewertung von Unternehmungen und Unternehmungsanteilen. Betriebswirtschaftliche Forschung Praxis 52(5):454-465

Opp K (1985) Sociology and economic man. Z Gesamte Staatswissenschaft 141(2):213-243

Palan S (2009) Bubbles and crashes in experimental asset markets. Springer, Berlin

Pierdzioch C, Rülke JC, Stadtmann G (2012) A note on forecasting emerging market exchange rates: evidence on anti-herding. Rev Int Econ 20(5):974-984. https://doi.org/10.1111/roie.12007

Prockl F, Frick B (2018) Information precision in online communities: player valuations on www.transfermarkt.de. Int J Sport Financ 13(4):319-335

Ramcke Y (2018) Status quo of media rights in European football: can we do better than no-single-buyer rule? https://www.offthefieldbusiness.de/single-post/2018/12/16/Status-Quo-of-Media-Rights-inEuropean-Football. Accessed 23 June 2019

Richau L, Follert F, Frenger M, Emrich E (2019) Performance indicators in football: the importance of actual performance for the market value of football players. Sciamus Sport Manag 4:41-67

Rohde M, Breuer C (2016) The financial impact of (foreign) private investors on team investments and profits in professional football: empirical evidence from the premier league. Appl Econ Financ 3(2):243-255. https://doi.org/10.11114/aef.v3i2.1366

Rohde M, Breuer C (2017) The market for football club investors: a review of theory and empirical evidence from professional European football. Eur Sport Manag Q 17(3):265-289. https://doi. org/10.1080/16184742.2017.1279203

Rosen S (1981) The economics of superstars. Am Econ Rev 71(5):845-858

Rosser JB, Rosser MV, Gallegati M (2012) A Minsky-Kindleberger perspective on the financial crisis. J Econ Issues 46(2):449-458. https://doi.org/10.2753/JEI0021-3624460220

Saqib O (2001) The East Asian crisis in Kindleberger-Minskys framework. Braz J Polit Econ 21(2):91-98

Scelles N, Szymanski S, Dermit-Richard N (2018) Insolvency in French soccer: the case of payment failure. J Sports Econ 19(5):603-624. https://doi.org/10.1177/1527002516674510

Schubert M, Lopez Frias FJ (2019) Walk the talk: financial fairness in European club football. Sport Ethics Philos 13(1):33-48. https://doi.org/10.1080/17511321.2017.1371790

Shiller RJ (2015) Irrational exuberance, 3rd edn. Princeton University Press, Princeton

Sloane PJ (1971) The economics of professional football: the football clubs as a utility maximiser. Scott J Polit Econ 18(2):121-146. https://doi.org/10.1111/j.1467-9485.1971.tb00979.x

Sloane PJ (2015) The economics of professional football revisited. Scott J Polit Econ 62(1):1-7. https:// doi.org/10.1111/sjpe.12063

Smith R (2019) Has the Premier League transfer bubble burst? The New York Times. https://www.nytim es.com/2019/02/01/sports/premier-league-transfer-window.html. Accessed 4 May 2020

Sornette D, Zhou WX (2004) Evidence of fueling of the 2000 new economy bubble by foreign capital inflow: implications for the future of the US economy and its stock market. Phys A 332:412-440. https://doi.org/10.1016/j.physa.2003.10.010

Speight A, Thomas D (1997) Football league transfers: a comparison of negotiated fees with arbitration settlements. Appl Econ Lett 4(1):41-44. https://doi.org/10.1080/758521830

Spyrou S (2013) Herding in financial markets: a review of the literature. Rev Behav Financ 5(2):175-194. https://doi.org/10.1108/RBF-02-2013-0009 
Storm RK, Nielsen K (2012) Soft budget constraints in professional football. Eur Sport Manag Q 12(2):183-201. https://doi.org/10.1080/16184742.2012.670660

Szymanski S (2017) Entry into exit: insolvency in English Professional Football. Scott J Polit Econ 64(4):419-444. https://doi.org/10.1111/sjpe.12134

Szymanski S, Weimar D (2019) Insolvencies in professional football: a German Sonderweg? Int J Sport Financ 14(1):54-68

Transfermarkt.de (2019) Transfereinnahmen und -ausgaben. https://www.transfermarkt.de/statistik/einna hmenausgaben

Tunaru RS, Viney HP (2010) Valuations of soccer players from statistical performance data. J Quant Anal Sports 6:2. https://doi.org/10.2202/1559-0410.1238

UEFA (2017) The European Club footballing landscape financial year 2015. https://www.uefa.com/Multi mediaFiles/Download/Tech/uefaorg/General/02/42/27/91/2422791_DOWNLOAD.pdf. Accessed 27 Aug 2019

UEFA (2018) The European Club footballing landscape financial year 2016. https://www.uefa.com/Multi mediaFiles/Download/OfficialDocument/uefaorg/Clublicensing/02/53/00/22/2530022_DOWNL OAD.pdf. Accessed 27 Aug 2019

UEFA (2019) The European Club footballing landscape financial year 2017. https://www.uefa.com/Multi mediaFiles/Download/OfficialDocument/uefaorg/Clublicensing/02/59/40/27/2594027_DOWNL OAD.pdf. Accessed 27 Aug 2019

UEFA (2020) The European Club footballing landscape financial year 2018. https://www.uefa.com/Multi mediaFiles/Download/OfficialDocument/uefaorg/Clublicensing/02/64/06/95/2640695_DOWNL OAD.pdf. Accessed 23 Feb 2020

Veblen T (1973) The theory of the leisure class: an economic study of institutions. Introduction John Kenneth Galbraith. Houghton Mifflin Company, Boston

Vogel HL (2010) Financial market-bubbles and crashes. Cambridge University Press, New York

Warshaw A (2002) Clear vision with transfer windows. https://www.uefa.com/news/newsid=33554.html. Accessed 19 Aug 2019

Weimar D, Fox A (2012) Fananleihen als Finanzierungsmöglichkeit von Sportclubs? Eine Bestandsaufnahme am Beispiel der Fußballbundesliga. Corp Financ biz 4:181-187

Weimar D, Wicker P (2017) Moneyball revisited: effort and team performance in professional soccer. J Sports Econ 18(2):140-161

Wicker P, Prinz J, Weimar D, Deutscher C, Upmann T (2013) No pain, no gain? Effort and productivity in professional soccer. Int J Sport Financ 8(2):124-139

Publisher's Note Springer Nature remains neutral with regard to jurisdictional claims in published maps and institutional affiliations. 